\title{
Astronomi Islam Era Dinasti Mamalik (1250-1517)
}

\author{
Arwin Juli Rakhmadi Butar-Butar \\ Institute of Arabic Research and Studies (IARS), Kairo-Mesir. \\ Email: juli_rakhmadi@gmail.com
}

\begin{abstract}
Astronomy is special scientific discipline in Islam as it relates to daily Muslim worship practices. In the Mamalik era (1250-1517), especially in Cairo and Damascus regions, Islamic astronomy has developed significantly as can be seen in the new discoveries of astronomical instruments. However, Islamic astronomy in the era of Mamalik conceals a very large amount of scientific knowledge that needs further discussion. As mentioned by King, there were a dozen of Islamic schbolars in astronomy whose treatises and ideas are unrevealed. Therefore contemporary astronomical studies run in higher educational institutions, should also seriously be focused on examining classical knowledge in astronomy. This article discusses the history and development of Islamic astronomy in the era of Mamalik and their contribution to the body of scientific knowledge in astronomy in that period.

Keyword: Mamalik, astronomy, history of science, and astrolabe.
\end{abstract}

\section{ABSTRAK}

Astronomi adalah bidang khusus dalam Islam yang terkait dengan kepentingan praktik peribadatan Muslim sehari-hari. Pada masa Mamalik (12501517), khususnya di wilayah Kairo dan Damaskus, astronomi Islam berkembang secara signifikan yang diantaranya dibuktikan dengan temuan-temuan alat-alat astronomi. Meski demikian, astronomi Islam pada masa Mamalik juga memiliki banyak sumber pengetahuan ilmiah yang perlu dikaji lebih dalam. Artinya, masih banyak tokohtokoh ilmuan di bidang astronomi yang belum pernah dikaji. Oleh karena itu, studi-studi astronomi dewasa ini di peruruan-perguruan tinggi harus secara serius juga difokuskan pada kajian pengetahuan klasik di bidang astronomi. Tulisan ini mendiskusikan tentang sejarah dan perkembangan ilmu astronomi Islam pada era Mamalik dan kontribusinya terhadap batang tubuh ilmu pengetahuan di bidang astronomi pada periode tersebut.

Kata Kunci : Mamalik, astronomi, sejarah ilmu pengetahuan, and astrolabe.

\section{PENDAHULUAN}

Tidak dipungkiri, dalam sejarahnya Mesir telah dilalui oleh banyak dinasti-dinasti (baca: kerajaan-kerajaan) Islam, dimulai dari era Tuluniyah, Ikhsyidiyah, Ayyubiyah, Mamalik, dan 'Utsmani, hingga era mantan Presiden Hosni Mubarak. Para peneliti dan sejarawan sains mengungkapkan, dari sekian banyak dinasti-dinasti yang pernah berkuasa tersebut, dinasti Mamalik (1250$1517 \mathrm{M}$ ) adalah dinasti yang paling menarik dan mengagumkan secara keilmuan. Berbagai kemajuan dibidang banyak dicapai di era ini, bahkan efeknya masih dapat dirasakan hingga kini, seperti keindahan 
bangunan-bangunan kuno Mamalik yang terdapat di kawasan Bab al-Futuh hingga kawasan Husein, keindahan mesjid Sultan Hasan, dan lain-lain. Secara keilmuan, era Mamalik memang cukup matang, berbagai kemajuan dibidang ilmu pengetahuan (sains) banyak tercapai. Berbagai kemajuan ini tidak terlepas dari peran para penguasa ketika itu yang memberi dukungan kepada para ulama dan ilmuan untuk mengembangkan penelitiannya. Disiplin astronomi adalah kajian yang tidak luput mendapat perhatian dan dukungan dari raja-raja Mamalik ketika itu seperti ditunjukkan oleh Zahir Baibar.

Di era kontemporer, betapapun kajian astronomi Islam era Mamalik telah banyak dilakukan ${ }^{1}$, namun kegemilangan astronomi era ini masih menyimpan banyak misteri yang harus diungkap oleh para peneliti dan sejarawan. Corak (karakter) astronomi yang berkembang di era Mamalik yang berbeda dari era sebelumnya menjadikan kajian astronomi era Mamalik ini menjadi menarik dan istimewa untuk dikaji. Secara umum corak (karakter) astronomi era Mamalik dapat dilihat dan dibedakan dengan era sebelum maupun sesudahnya melalui alat-alat astronomi yang digunakan yang lebih bersifat praktis, seperti untuk kepentingan penentuan waktu-waktu salat, menentukan arah kiblat, menentukan awal bulan, dan sebagainya. Sisi lain, kecendrungan kajian astrologi (nujum) yang telah mulai berkurang secara drastis di era ini. King menuturkan, astrologi yang banyak dipraktikkan pada abad pertengahan, namun sangat mengejutkan karya-karya astrologi di era Mamalik sangat sedikit sekali yang dapat diteliti. ${ }^{2}$

Tulisan ini mencoba menelusuri lebih jauh gagasan-gagasan astronomi Islam era Mamalik berikut tokoh-tokoh dan karya- karya mereka dan sejauh mana urgensinya terhadap kajian astronomi kontemporer.

\section{DINASTI MAMALIK: KEMUNCULAN DAN PERIKEMBANGAN}

Menurut Hitti, kemunculan dan kebangkitan dinasti Mamalik merupakan fenomena yang sulit dipahami. ${ }^{3}$ Dinasti Mamalik terbentuk melalui akmulasi dan akulturasi berbagai suku dan bangsa dari kalangan budak yang menciptakan suatu tatanan komunitas. Dinasti Mamalik menguasai dua wilayah strategis, Mesir dan Syria. Dalam sejarahnya, Mamalik berhasil menahan laju invasi pasukan Mongol dibawah pimpinan Hulagu dan Timur Lenk. Para sejarawan menganggap, apabila Mamalik gagal mempertahankan wilayahnya dari serangan pasukan Mongol ini, dapat dipastikan seluruh tatanan sejarah dan kebudayaan di Asia Barat dan Mesir akan runtuh, kesinambungan kebudayaan dan peradaban tidak akan dapat disaksikan lagi. ${ }^{4}$

Fondasi kekuasaan Mamalik diletakkan oleh Syajarah ad-Durr, penguasa wanita muslim yang berkuasa di kawasan Afrika Utara dan Asia Barat dari Dinasti Ayyubiyah, yang hanya berkuasa selama 80 hari. Ia adalah seorang budak sekaligus istri (selir) alMusta'shim. Sementara Aibak (1250-1257 M) adalah Sultan Mamalik pertama dalam sejarah Dinasti Mamalik. Dalam perjalanannya, Mamalik terbagi kepada dua dinasti besar: Bahri (1250-1390) dan Burji (1382-1517 M). ${ }^{5}$ Raja Mamalik paling tersohor adalah Zahir Baibar (1260-1277 M) ${ }^{6}$, ia pada awalnya seorang budak yang dibeli oleh Raja Salih dan diangkat sebagai pemimpin pasukan. ${ }^{7}$ Baibar pernah mengalahkan pasukan Mongol, ia juga tercatat dalam perjuangannya melawan tentara Salib, dan ia juga banyak 
melakukan penaklukan-penaklukan. Kemampuan Baibar tidak hanya sebatas dalam bidang militer, selain berhasil mengorganisir pertahanan (militer), ia membangun angkatan laut, menggali sejumlah kanal, memperbaiki pelabuhan, dan yang terpenting ia menghubungkan Kairo dan Damaskus yang menjadi akses penyebaran dan pertukaran informasi dan ilmu pengetahuan. Di bidang keagamaan, Baibar mengangkat empat orang hakim (kadi) yang mewakili empat mazhab populer (Maliki, Hanafi, Syafi'i dan Hanbali). ${ }^{8}$

Akhir kekuasaan Dinasti Mamalik terjadi pada tahun 1517 M pada saat Raja Salim dari Dinasti Utsmani berhasil menggulingkan kekuasaan yang sedang berkuasa ketika itu.

\section{KONDISI SOSIO-RELIGIUS DAN INTELEKTUAL ERA MAMALIK}

Sejarah mencatat, penaklukan Mongol terhadap kota Bagdad pada tahun $656 \mathrm{H} /$ $1258 \mathrm{M}$ memberi perubahan drastis terhadap dunia Islam secara umum. Penaklukan ini menandai pula berpindahnya pusat kebudayaan dan ilmu pengetahuan dari kota Bagdad ke kota Kairo dan Damaskus. Ada beberapa faktor yang menjadikan kawasan Mamalik (khususnya Kairo dan Damaskus) ini menjadi pusat ilmu, diantaranya adalah perhatian serius penguasa-penguasa Mamalik pada masa itu terhadap ilmu pengetahuan yang ditandai dengan optimalisasi peran ulama (ilmuwan) dalam pengembangan ilmu. Pada periode ini, halakah-halakah ilmu demikian marak, penelitian-penelitian juga mendapat dukungan dana dari penguasa. Selain itu, hilangnya dominasi Bagdad secara keseluruhan dari dunia Islam secara politik, secara otomatis menjadikan posisi Kairo dan Damaskus menjadi semakin penting.
Puncaknya ditandai dengan eksodus ulama dari kota Bagdad ke kota Kairo dan Damaskus. ${ }^{9}$

Dalam perkembangannya, kehidupan ilmiah era Mamalik benar-benar mencapai puncak dan menjadikannya sebagai pusat ilmu dan ulama dunia. Raja-raja Mamalik memiliki peran besar dalam pengembangan ilmu, khususnya di Mesir. Selain itu, para raja Mamalik juga memiliki semangat dalam ilmu, seperti ditunjukkan Zahir Baibar, yang senantiasa menghidupkan dan berpartisipasi dalam diskusi agama dan ilmu pengetahuan. ${ }^{10}$

Bagaimanapun, disamping berbagai kelemahan yang tetap ada, sejarah panjang yang dilalui dinasti Mamalik, khususnya di Mesir dan Syria, telah melahirkan berbagai kemajuan dalam berbagai bidang, khususnya bidang politik dan keilmuan. ${ }^{11}$ Dalam bidang keilmuan, Mamalik terus berkembang dan memunculkan ulama (ilmuwan) dalam jumlah yang banyak dalam berbagai bidang disiplin ilmu. Al-Qalqasyandi (w. $821 \mathrm{H}$ ) menuturkan bahwa karya-karya tulis pada masa ini (baca: era Mamalik) sangat melimpah, khususnya karya-karya dalam bidang agama (Islam). ${ }^{12}$

\section{SUMBANGAN DAN PERIEMBANGAN ASTRONOMI}

Dengan posisi pusat ilmu yang dimiliki Mamalik tak pelak menjadikan kota Kairo dan Damaskus dan wilayah-wilayah kekuasaan Mamalik lainnya menjadi mercusuar ilmu pengetahuan dunia. Dalam bidang astronomi, Mesir dan Syria, pada masanya telah memiliki tradisi astronomi yang matang. Tradisi penelitian dan observasi menjadi bagian integral para astronom ketika itu. Secara lebih spesifik, astronomi Islam era Mamalik telah memiliki corak dan karakter 
tersendiri yang membedakan dengan astronomi sebelumnya. Sebelum era Mamalik, kajian astronomi cendrung bersifat Ptolemaik atau astronomi matematis (falak riyadhi) yang bersumber dari 'Almagest'. Namun di era Mamalik, astronomi mulai mengalami pergeseran ke arah alami atau thabi'i (falak fiziya'i, astrofisika) yang memokuskan pada keserasian dan keselarasan dengan gambaran ilmiah terhadap alam, bersifat paraktis dan berdasarkan pengamatan. ${ }^{13}$ Secara lebih spesifik, astronomi Islam era Mamalik lebih diarahkan pada hal-hal yang bersifat praktis seperti menentukan waktu-waktu salat, arah kiblat, penentuan hilal (bulan sabit) awal bulan, dan lain-lain. Berbagai kreasi dan akselerasi astronom Mamalik ini diantaranya termanifestasikan dalam bentuk alat-alat dan dokumntasi perhitungan (zij).

\section{INSTRUMEN ASTRONOMI}

Instrumen (alat-alat) astronomi adalah sarana observasi ilmiah yang digunakan para astronom Islam dalam mengungkap fenomena alam. Fungsi alat-alat ini adalah untuk menghitung (menentukan) peredaran benda-benda langit: bumi, bulan, matahari dan planet-planet secara akurat. Selain itu, alat-alat ini juga digunakan untuk mempresisikan perhitungan segitiga bola secara cermat. ${ }^{14}$ Instrumen astronomi merupakan unsur asasi untuk berdiri dan beroperasinya sebuah observatorium (almarshad). Para astronom Mamalik dimasanya telah berhasil mengembangkan dan memperluas penggunaan alat-alat ini.

Secara umum, peradaban Islam era Mamalik adalah peradaban yang banyak melahirkan alat-alat astronomi yang beberapa diantaranya terus digunakan hingga kini.
Alat-alat ini beberapa diantaranya merupakan lanjutan dan penyempurnaan dari alat-alat astronomi yang pernah dikembangkan di peradaban sebelumnya, khususnya dari peradaban Yunani seperti: astrolabe, dzawat al-halq, arba' ad-da'irah, alkurrat al-ardhiyyah wa as-Samawiyyah, sa'ah syamsiyyah (jam matahari), dan lain-lain. Alatalat ini di era Mamalik terus dikembangkan dengan berbagai perbaikan dan modifikasi hingga lebih efektif.

Oleh karena itu, di peradaban Islam era Mamalik telah dihasilkan banyak pengembangan signifikan terhadap instrumen-instrumen astronomi berikut rumusan teori-teorinya yang akurat pada zaman itu. Bentuk konkrit kontribusi tersebut berupa pengembangan dan modifikasi alat-alat yang sudah ditemukan terdahulu, khususnya dari Yunani, dan penemuan-penemuan instrumen baru yang belum ditemukan sebelumya.

Penemuan dan pengembangan ini sangat penting, karena instrumen astronomi adalah unsur utama dan mempunyai pengaruh besar bagi kemajuan sebuah peradaban.

Berkembang atau tidaknya ilmu astronomi disuatu peradaban (bangsa) bisa di lihat dari alat-alat yang ditemukan. Karena percobaan dan penelitian yang notabenenya menghasilkan pengetahuan, sangat erat hubungannya dengan alat-alat yang digunakan. Dan dengan kelengkapan alat sebuah penelitian akan menemukan hasil yang lebih akurat.

Adapun beberapa instrumen astronomi yang berkembang dan populer pada masa Mamalik antara lain:

\section{Al-usthurlab (Astrolabe)}

Atrolabe merupakan perkakas astronomi 
kuno yang digunakan untuk mengukur kedudukan, bentuk dan fenomena langit. Alat ini telah dikenal sejak zaman Yunani. Seperti dituturkan an-Nadim (w. 388 H) dalam "al-Fihrist" nya, ulama astronomi Islam yang pertama sekali membuat astrolabe adalah Ibrahim al Fazzari (w. \pm 180 H). ${ }^{15}$ Astrolabe terdiri dari lempengan (piringan) dengan ukuran 360 derajat dan terbagi-bagi dalan seperempat lingkaran ( $a r b a$ ' ad-da'irah) yang tertera didalamnya nama-nama zodiak (rasi bintang), angka-angka derajat, dan lainlain. Alat ini berbentuk bulat yang menggambarkan bola langit yang terdiri dari garis atau skala yang menunjukkan posisiposisi bintang atau benda-benda angkasa. Alat ini juga bersisi angka-angka atau hurufhuruf dalam format 'hisab al-jummal'. ${ }^{16}$

Al-Khawarizmi (w. 387 H) dalam 'Mafatih al-'Ulum'nya mendefinisikan alat ini sebagai "miqyas an-nujum" (pengukur bintang), berasal dari bahasa Yunani yaitu 'astrolabio', 'astro' berarti bintang dan 'labio' berarti pengintai atau pengukur (mir'ah). ${ }^{17}$ Sementara Hajji Khalifah (w. 1068 H) dalam 'Kasyf azhZhunun'nya menjelaskan secara lebih detail pengertian dan fungsi astrolabe, yaitu suatu ilmu yang membahas tata cara mengetahui keadaan bintang-bintang secara lebih mudah dan teliti, seperti mengetahui ketinggian matahari, terbit-tenggelamnya, mengetahui zenit kiblat, mengetahui lintang tempat, dan lain-lain. ${ }^{18}$

Sejak masuk peradaban Islam, astrolabe sudah menjadi satu disiplin ilmu spesifik dimana banyak astronom Islam yang mendalami alat ini dalam teori dan praktik. Di era Mamalik, astrolabe dimodifikasi lebih baik dengan berbagai penyempurnaan. Tercatat, Ibn Syathir (w. 777 H) adalah diantara astronom era Mamalik yang memiliki kemahiran dalam teori dan praktik terhadap alat ini, diantara karyanya dalam bidang ini adalah: "Risalah Ibn asy-Syathir fi Ushul 'Ilmil Usthurlab". Selain Ibn asy-Syathir, al-Mizzi (w. $750 \mathrm{H}$ ) juga piawai dalam alat ini, diantara karyanya: "Risalah al Mizzy fil Usthurlab".

\section{Al-Mizwalah (Sundial, Jam Matahari)}

Sundial atau Jam Matahari adalah alat astronomi kuno yang digunakan sebagai penunjuk waktu melalui bayang-bayang matahari. Dalam bahasa Arab alat ini disebut 'mizwalah' atau 'sa'ah syamsiyyah'. Diduga, para astronom Islam menemukan dan mengembangkan alat ini sejak abad $1 \mathrm{H} / 7 \mathrm{M}$ dari warisan peradaban Yunani dan Romawi. Dalam praktiknya, alat ini hanya bisa berfungsi dengan memanfaatkan bayangbayang matahari. ${ }^{19}$ Dalam penggunaan dan pembuatannya, dasar-dasar matematika sedikit dibutuhkan dalam memahami dan menerapkan alat ini, meski tidak terlalu sulit.

Mizwalah (Sundial, Jam Matahari) ditemukan melalui pemahaman mendalam terhadap teori segitiga bola atau trigonometri (hisab al mutsallatsat). Sampai saat ini Jam Matahari masih dipakai dan dipelihara orang sebagai ornamen yang menunjukkan keunikan dan keilmuan astronomi Islam silam yang terus terabadikan dalam sejarah dan peradaban. Alat ini memberi informasi pula tentang bagaimana orang-orang terdahulu mengidentifikasi waktu dan aktifitas mereka. Para astronom era Mamalik banyak memberi kontribusi dalam pengembangan alat ini, baik teori maupun terapan. Ini terbukti pada zaman itu alat ini banyak ditemukan di pelataran mesjid-mesjid. Ibn Syathir (w. $777 \mathrm{H}$ ) pada tahun $1371 \mathrm{M}$ / $1372 \mathrm{M}$ tercatat pernah membuat Jam 
Matahari Datar (Mizwalah Ufuqiyyah) berukuran 2 meter diletakkan di pelataran Mesjid Umawiyah di Damaskus - Syria, sementara sebagian bagiannya ada di taman Museum Nasional Damaskus. ${ }^{20}$ David A. King menyatakan, Mizwalah Ibn Syathir terhitung sebagai kreasi, temuan dan sampel luar biasa yang menunjukkan keindahan seni ilmiah, Mizwalah ini juga terhitung sebagai Mizwalah terindah di abad pertengahan (era Mamalik). ${ }^{21}$

Teks otentik tentang Mizwalah yang ditemukan di era Mamalik dan banyak dimanfaatkan oleh para peneliti adalah "Jami' al-Mabadi' wa al-Ghayat fi 'Ilm al-Miqat" karya al-Hasan bin Ali al-Marrakusyi (abad 7 $\mathrm{H} / 13 \mathrm{M}){ }^{22}$ Karya ini terhitung sebagai karya komprehensif tentang Mizwalah dan teoriteorinya. King mengungkapkan, sejatinya alat yang dikembangkan al-Marrakusyi ini perlu ditindak lanjuti dengan melakukan penelitian komprehensif dengan perangkat alat-alat modern. ${ }^{23}$

\section{Rub' Mujayyab (alat seperempat lingkaran)}

Rub' Mujayyab adalah alat astronomi klasik berbentuk seperempat lingkaran dengan desain sederhana hasil kreasi astronom Islam silam yang multi fungsi, khususnya untuk memecahkan permasalahan-permasalahan astronomi bola (falak kurawy). Alat ini berfungsi untuk menentukan arah kiblat, menentukan waktuwaktu salat, menentukan ketinggian suatu benda, dan lain-lain. Alat ini disebut juga dengan rub' da'iri atau dzat ar-rub' atau arrub'iyyah. ${ }^{24}$ Alat ini bisa terbuat dari kayu, tembaga maupun logam mulia. Alat ini terdiri dari busur yang terbagi kepada 90 derajat, dimana pada busur tersebut tertera nomor-nomor yang menunjukkan waktu. Di bagian tengahnya terdapat garis lurus lengkung saling menyilang dan memotong. Alat ini dalam penggunaanya hampir mirip dengan astrolabe yang mampu memecahkan banyak persoalan perhitungan astronomismatematis.

Sampai abad 8 H/14 M, di Syria, alat ini masih banyak beredar dan digunakan. ${ }^{25}$ Dahulu, alat ini juga digunakan oleh para pelaut untuk menentukan Lintang \& Bujur, menentukan arah kapal, dan lain-lain. ${ }^{26}$ Astronom Islam Ibn Syathir (w. 777 H) menulis banyak karya tentang alat-alat ini berikut tata cara pembuatan dan penggunaannya, antara lain dalam karyakaryanya sebagai berikut: Kifayah al-Qanu' $f i$ al-Amal bi ar-Rub' al-Maqthu', Risalah fi al'Amal bi Rub' asy-Syakaziyyah, Risalah al-'Amal bi Rub' al-Jami', an Naf' al-'Am fi al-'Amal bi Rub' at-Tam li Mawaqit al-Islam, Idhah alMughib fi al-'Amal bi ar-Rub' al-Mujayyab, dan lain-lain.

\section{Zij (Tabel Astronomi)}

Dalam terminologi klasik, zij adalah daftar astronomis hasil observasi dan kalkulasi (hisab) para astronom silam terhadap bendabenda langit seperti planet-planet, bintangbintang dan benda-benda langit lainnya yang berkaitan dengan gerak, jarak dan posisi hariannya. ${ }^{27}$ Al-Akfani (w. 749 H/1348 M) dalam karyanya "Irsyad al-Qashid Ila Asna alMaqashid" menyebutkan, cabang ilmu astronomi (hai'ah) ada 5: (1) ilmu zij dan kalender, (2) ilmu waktu, (3) ilmu tata cara observasi, (4) ilmu tentang alat-alat astronomi, (5) ilmu tentang alat-alat bayangan benda. ${ }^{28}$ Al-Akfani menguraikan, yang dimaksud ilmu zij dan kalender ('ilm azzaijat wa at-taqawim) adalah ilmu untuk 
mengetahui ukuran planet-planet yang beredar (al-kawakib as-sayyarah) yang tersebar dari asal usul yang universal. ${ }^{29}$

Sementara itu praktisi astronomi Islam kontemporer Indonesia, Prof. Dr. Susiknan Azhari, MA., menyatakan kata zij berasal dari bahasa Sansekerta, yang masuk ke bahasa Arab dan Persia melalui bahasa Pahlavi, yang berarti tabel astronomi. Tapi sebenarnya kebanyakan Zij tak hanya memuat tabel, juga pembahasan teori astronomi, bab tentang kronologi, penjelasan luas hal astronomi matematis dan subyek lain yang berhubungan. Zij yang merupakan satu bagian penting literatur ilmu falak, biasanya dinamakan menurut penyusunnya atau penunjang atau kota, tempat ia disusun, walaupun sering pula digunakan cara penamaan yang lain. ${ }^{30}$

Zij merupakan dasar dan perangkat penomoran (numerical tables) yang dimanfaatkan para astronom dan astrolog, seperti mengukur dan menghitung peredaran dan posisi planet, bintang dan fenomena gerhana. Tabel-tabel ini juga berfungsi sebagai data verifikasi teori sekaligus laporan observasi berdasarkan data yang sudah terdokumentasi. Bahkan data (tabel) ini juga berfungsi merekonstruksi model geometri seperti perangkat-perangkat dalam matematika.

Era Mamalik, terdapat banyak karya-karya model ini, diantaranya adalah: "ad-Durr alYatim" karya Ahmad bin Rajab al-Majdi (w. 850 H). Terhadap zij ini, King dan Kennedy telah melakukan kajian tentang teori-teori dalam zij ini. King menuliskan penelitiannya ini dalam artikelnya yang berjudul "Ibn alMajdi's Table for Calculating Ephemerides". ${ }^{31}$

\section{Mikat, Muwaqqit \& Institusi Astronomi}

Di era Mamalik, para astronom pada umumnya berprofesi sebagai miqati atau muwaqqit, yaitu astronom profesional yang berasosiasi kepada salah satu mesjid atau institusi agama yang bertugas menentukan waktu-waktu salat. Selain itu, terdapat juga sejumlah astronom Islam yang berprofesi sebagai miqati atau muwaqqit namun tidak berasosiasi kepada salah satu mesjid atau institusi agama. ${ }^{32}$ Disiplin ilmu ini belum muncul di peradaban sebelum Islam. Mikat merupakan disiplin keilmuan Islam asli hasil akselerasi dan kreasi astronom muslim khususnya era Mamalik. Menurut King, dasar-dasar miqat pertama kali dimunculkan Ibn Yunus (w. 399 H) ${ }^{33}$, astronom Muslim terbesar asal Mesir, dan di era Mamalik, tepatnya abad $7 \mathrm{H} / 13 \mathrm{M}$ ilmu ini mengalami kegemilangan dan menjadi suatu disiplin ilmu matang. ${ }^{34}$

Mikat merupakan cabang astronomi yang berkaitan dengan pengaturan waktu (timekeeping) berdasarkan rotasi harian matahari dan bintang-bintang untuk penentuan waktu dan khususnya mendefinisikan waktu-waktu salat. ${ }^{35}$ Dalam peradaban Islam, berbagai hasil perhitungan dan observasi yang dilakukan pada umumnya tercatat dalam sebuah tabel (zij), yaitu tabel waktu-waktu. Mikat pada dasarnya merupakan bagian dari ilmu zij yang mempelajari tentang rotasi harian matahatri dan benda-benda angkasa.

Diantara muwaqqit Islam terkenal era Mamalik adalah al-Hasan bin Ali alMarrakusyi (abad 7 H/13 M). Ia berasal dari Marakesh (Maroko), namun ia bekerja dan berkiprah di Kairo. Karya terbesarnya adalah "Jami' al-Mabadi' wal Ghayat fi 'Ilm al-Miqat". Buku ini menyajikan sebuah pekerjaan yang sangat eklektik, bahkan menyajikan survei lengkap tentang astronomi bola dan instrumen astronomi.

Selain al-Marrakusyi, muwaqqit Islam 
lainnya adalah Syihab ad-Din al-Maqsi (w. 675 $\mathrm{H} / 1276 \mathrm{M}$ ), yang telah melakukan dua pekerjaan besar, yaitu sebuah risalah tentang teori jam matahari dan satu set tabel untuk ketepatan waktu-waktu salat (timekeeping).

\section{Tokoh-Tokoh Astronomi Era Mamalik}

Berdasarkan penelitian yang dilakukan King, terdapat sekitar 75 tokoh (astronom) Islam yang pernah eksis di era Mamalik. ${ }^{36}$ Satu hal yang menarik, King menetapkan Jalal ad-Din as-Suyuthi (w. $911 \mathrm{H}$ ) sebagai salah satu astronom era Mamalik. Namun dari sekian banyak tokoh-tokoh astronomi yang disebutkan King tersebut hanya segelintir tokoh saja yang biografinya tertera dalam buku-buku bibliografi, baik klasik maupun kontemporer. Ini mengindikasikan perlunya dilakukan kajian komprehensif terhadap karya-karya astronomi era Mamalik demi mengungkap tokoh dan gagasan astronomi di masa itu secara lebih akademis.

Berikut adalah beberapa astronom Islam era Mamalik dan beberapa karya-karya mereka yang dikutip dari berbagai sumber:

- Ibn asy-Syathir (w. 777 H). Karya: Kifayah al-Qanu' fi al-'Amal bi ar-Rub' al-Maqthu', Risalah fi al-'Amal bi Rub' asy-Syakaziyyah.

- Jamal ad-Din al-Mardini (w. 843 H). Karya: Risalah 'ala ar-Rub' al-Mujayyab 'ala anna alBakhsy fi Thariq al-Qaus, Muqaddimah fi Ma'rifah al-'Amal bi Rub' asy-Syakaziyyah.

- Muhammad bin Muhammad al-Ghuzuli (w. 745 H). Karya: Risalah fi Shafhah al'Amal bi ar-Rub' al-Mujayyab, al-Jaib alGha'ib.

- Ibn al-Ha'im (w. 815 H). Karya: al-Luma' fi al-Hisab.

- Sibth al-Mardini (w. 912 H). Karya: Hawi al-Mukhtasharat fi al-'Amal bi Rub' alMuqantharat, Hidayah al-Ha'ir li Wadh'
Fadhl ad-Da'ir.

- Muhy ad-Din al-Maghribi (w. \pm 680 H). Karya: Kitab Tasthih al-Usthurlab, Kitab Taj al-Azyaj wa Ghunyah al-Muhtaj.

- Dhiya' ad-Din ad-Dirini (w. 694 H). Karya: al-Yawaqit fi 'Ilm al-Mawaqit.

- Al-Hasan bin Ali al-Marrakusyi (abad 7 H/ 13 M). Karya: Jami' al-Mabadi' wa al-Ghayat fi 'Ilm al-Miqat, Risalah Talkhish al-'Amal fi Ru'yah al-Hilal.

- Syihab ad-Din al-Maqsi (w. 675 H). Karya: Syifa' al-Asyqam fi Wadh' as-Sa'at 'ala arRakham, Ghayah al-Intifa' fi Ma'rifah adDa'ir min Qibali al-Irtifa'.

- Abu Ali al-Farisi (w. 677 H). Karya: Maqashid Dzaw al-Albab fi al-'Amal bi alUsthurlab, Nihayah al-Idrak fi Asrar 'Ulum alAflak.

- Ibn Sim'un (w. 737 H). Karya: al-Ushul alMutsmirah fi al-'Amal bi Rub' al-Musyathirah, Kanz ath-Thullab fi al-'Amal bi al-Usthurlab.

- Ibn as-Sarraj (w. 726 H). Karya: Risalah alUsthurlab wa al-Jaib al-Gha'ib, Risalah al'Amal bi Rub' al-Muqantharat.

- Zain ad-Din al-Mizzi (w. 750 H). Karya: Risalah al-Mizzi fi al-Usthurlab, ar-Raudhat azZahirat fi al-'Amal bi Rub' al-Muqantharat, Mukhtashar fi al-'Amal bi Rub' ad-Da'irah.

- Ahmad bin al-Kaum ar-Risyi (w. 836 H). Karya: Kifayah at-Ta'lim fi Wadh' at-Taqwim, al-Lum'ah fi Hall al-Kawakib as-Sab'ah.

- Ibn al-Atthar (w. 840 H). Karya: Kifayah alMusytaq li Ma'rifah Fadhl ad-Da'ir fi Sa'ir alAfaq, Risalah fi 'Urudh al-Bilad wa Athwaliha.

- Syihab ad-Din al-Halbi (w. 859 H). Karya: Bughyah ath-Thullab fi al-'Amal bi Rub' alUsthurlab, Jadwal Irtifa' al-Kawakib atsTsabitah 'Inda Thulu' al-Fajr.

- Ibn al-Ji'an (w. 930 H). Karya: Thawali' alBudur fi Tahwil as-Sinin wa asy-Syuhur. 
- Badr ad-Din al-Karadisi (w. 887 H). Karya: Muqaddimah fi 'Amal al-Hilal, Asykal alWasa'ith fi al-Munharifat wa al-Basa'ith.

- Muhammad bin Abi al-Fath ash-Shufi (w. 883 H). Karya: Bulugh al-Witr fi al'Amal bi al-Qamar, as-Sahl bi al-Hisab al-Mumti' fi al'Amal bi al-Basith al-Murtafi'.

- Jalal ad-Din as-Suyuthi (w. 911 H). Karya: al-Hai'ah as-Saniyyah fi al-Hai'ah asSunniyyah.

\section{KESIMPULAN}

Dua wilayah kekuasaan Dinasti Mamalik, Mesir dan Syria, adalah dua wilayah yang pada masanya menjadi mercusuar ilmu. Setelah jatuhnya Bagdad, secara praktis kota Kairo dan Damaskus menjadi pusat astronomi dunia Islam, bahkan dunia secara umum. Para astronom Mamalik pada umumnya beraktifitas pada berbagai bidang disiplin astronomi, seperti astronomi teoritis, astronomi praktis (falak asy-sya'b), geometri, astronomi bola (falak kurawi), perhitungan waktu (timekeeping), table-tabel waktu (zij), perbintangan (astrologi), dan alat-alat (instrumen) astronomi. Karena itu literaturliteratur manuskrip yang tersebar di berbagai perpustakaan dunia, dan alat-alat astronomi yang sebagiannya saat ini masih tersisa merupakan sumber informasi utama bagi para peneliti dan sejarawan kontemporer untuk menguak tradisi dan peran astronomi Islam era Mamalik. Beberapa peneliti kontemporer yang telah dan pernah melakukan penelitian di bidang ini antara lain David King, E.S. Kennedy, Carlo Nillino, dan lain-lain. Sejatinya penelitian-penelitian yang dilakukan oleh para orientalis ini memberi informasi berharga bagi umat Islam.

Namun demikian, mengingat banyaknya tokoh-tokoh astronomi berikut karya-karya mereka yang belum terungkap, hal ini memberi konsekuensi kepada kita untuk terus menggalakkan penelitian di bidang ini secara serius. Kajian-kajian astronomi Islam yang diselenggarakan di kalangan universitas hendaknya dapat lebih mengapresiasi turats astronomi Islam kalsik. Bagaimanapun, sumbangan para astronom Islam silam, baik berupa karya tulis maupun alat-alat astronomi dan peninggalan-peninggalan lainnya yang masih tersisa, merupakan kekayaan peradaban Islam yang harus dilestarikan dan dikembangkan secara akademis.

\section{CATATAN AKHIR}

1 Antara lain dilakukan oleh: David A. King, E.S. Kennedy, Carlo Nillino, dan lain-lain.

2 David A. King, The Astronomy of The Mamluks: A Brief Overview, h. 74

3 Philip K. Hitti, History of The Arabs, Terjemah: R. Cecep Lukman Yasin \& Dedi Slamet Riyadi (Indonesia: PT. Serambi Ilmu Semesta, cet. I, 1429/2008), h. 859.

4 Ibid.

$5 \quad$ Ibid., h. 862.

6 Nama lengkapnya: al-Malik azh-Zhahir Rukn ad-Din Baibar al-Bunduqdari.

7 Ibid., h. 864. Abu al-Fida', Taqwim al-Buldan, j. 3, h. 216.

Ibid., h. 865.

9 Dr. Zhamya' Abbas as-Samira'i, al-Hibat al-Haniyyat fi al-Mushannfat al-Ja'bariyyah, dalam Majalah "Ma'had al-Makhthuthat al-'Arabiyyah" edisi 54, j. 2 (Dzu alOa'dah 1431/November 2010), h. 7-8.

10 Lihat: analisa (dirasah) kitab "Ghunyah al-Fahin wa atThariq Ila Hall at-Taqwim" karya Ahmad bin Rajab alMajdi (w. 850 H), Tahkik \& Dirasah: Arwin Juli Rakhmadi (Tesis Master, 2008), h. 16.

11 Oashr al-Amir Thaz, Ibn Khaldun Baina al-Andalus wa Mishr (Kairo: 2008), h. 79.

12 Ahmad bin Ali al-Oalqasyandi, Shubh al-A'sya fi Shina'ah al-Insya', j. 1 (Kairo: al-Mu'assasah alMishriyyah li at-Ta'lif wa at-Tarjamah, t.t.), h. 467.

13 Lihat: analisa (dirasah) kitab "Ghunyah al-Fahin wa atThariq lla Hall at-Taqwim" karya Ahmad bin Rajab alMajdi, h. 7.

14 Ibid., h. 22.

15 An-Nadim, al-Fihrist, Editor: Muhammad Ahmad Ahmad, 
(Kairo: Maktabah Tawfiqiyyah, t.t.), h. 374.

16 Hisab al-Jummal adalah hisab atau perhitungan dengan menggunakan huruf Arab yang dari tiap-tiap hurufnya terdiri dari angka atau bilangan tertentu. Seperti huruf 'alif berarti satu, huruf ' $b a$ ' ' berarti dua, dst. Hisab model ini banyak tertera dalam literatur-literatur klasik (manuskrip) khususnya literatur Astronomi. (Lihat: 'Isham Mohammad el-Syanthy, Thuruq Ta'rikh an-Nusakh fi al-Makhthuthat: an-Nasy'ah wa al-Hall, (Diktat Mata Kuliah 'Fahrasah al Makhthuthaat' Institut Manuskrip Arab, Kairo, t.t.), h. 4.).

17 Al Khawarizmi, Mafatih al-'Ulum, Editor: G. Van Vloten, Pengantar: Muhammad 'Abd al-'Aziz (Serial adzDzakha'ir (118) al-Hai'ah al-'Ammah li Qushur atsTsaqafah-Kairo, 2004), h. 232.

18 Hajji Khalifah, Kasyf azh-Zhunun 'an Asamy al-Kutub wa al-Funun, j. 1, (Beirut: Dar Ihya' at-Turats al-'Araby, t.t.) h. 106.

19 'Abd al-Amir Mu'min, Oamus Dar al-'Ilm al-Falaky, (Beirut: Dar al-'Ilm li al-Malayin, cet. 1, 2006), h. 472.

20 David A. King, 'Ilm al-Falak wa al-Mujtama' al-Islami, dalam Mawsu'ah Tarikh al-'Ulum al-'Arabiyyah, j. 1, Editor: Rusydi Rasyid, (Markaz Dirasat al Wahdah al 'Arabiyyah \& Mu'assasah 'Abd al-Hamid Syuman), h. 214.

$21 \quad$ Ibid, h. 216.

22 Al-Marrakusyi adalah seorang ahli falak asal Maroko (Magrib), namun ia bekerja di Kairo sekitar tahun 1280 M. "Jami' al-Mabadi' wa al-Ghayat fi 'llm al-Miqat" karya al-Murrakisyi ini terdiri dua juz (130 fasal), karya ini memiliki pengaruh besar dimasanya khususnya Mesir dan Syria.

23 Ibid., h. 210.

24 Lihat lebih lanjut: Analisa (dirasah) kitab "Ghunyath alFahim wa at-Thariq ila Hall at-Taqwim" karya Ibn alMajdi (w. 850 H), h. 27.

25 Donald R. Hill, al-'Ulum wa al-Handasah fi al-Hadharah al-Islamiyyah, Terjemah: Ahmad Fu'ad Basya, (Kuwait: 'Alam al-Ma'rifah, 2004), h. 81.

26 Fatimah Mahjub, al Mawsu'ah az Dzahabiyyah li al'Ulum al-Islamiyyah, j. 19, (Kairo: Dar al-Ghad al-Araby,), h. 330.

27 Muhammad 'Ali at-Tahanawi, Kasysyaf Isthilahat al'Ulum wa al-Funun, j. 1, Tahkik: Dr. 'Ali Dahruj (Lebanon: Maktabah Lubnan Nasyirun, cet. I, 1996), h. 917, Carlo Nillino, 'Ilm al-Falak Tarikhuhu 'Inda al-'Arab fi al-Qurun al-Wustha (Kairo: Maktabah ats-Tsaqafah ad-Diniyyah, t.th.), h. 42.

28 Muhammad bin Ibrahim al-Akfani, Irsyad al-Oashid Ila Asna al-Maqashid, Tahkik: Abd al-Mun'im Mahmud Umar (Kairo: Dar al-Fikr al-Arabi, t.t.), h. 204.

29 Ibid., h. 205.

30 Susiknan Azhari, Ensiklopedi Hisab Rukyat, (Yogyakarta: Pustaka Pelajar, 2005).

31 Lihat: David A. King \& E.S.Kennedy, Ibn al-Majdi's Table for Calculation Ephemerides, dalam "Islamic Mathematical Astronomy" (Variorun Reprints, London 1886), h. 48.

32 David A. King, The Astronomy of The Mamluks, dalam "Islamic Mathematical Astronomy" (Variorun Reprints, London 1886), h. 534.

33 Lihat: David A. King, Astronomical Timekeeping in Fourteenth - Century Syria, dalam "Islamic Mathematical Astronomy" (Variorun Reprints, London 1886), h. 77.

34 Donald R. Hill, op.cit., h. 63.

35 David. A. King, Mikat, dalam "The Encyclopaedia of Islam", Volume VII (New Edition) (Leiden - New York: E.J. BRILL, 1993), h. 27.

36 Lihat daftar nama-nama astronom Mamalik hasil penelitian King dalam: David A. King, The Astronomy of The Mamluks, h. 553-555.

\section{DAFTAR PUSTAKA}

Ali al-Oaalqasyandi, Ahmad bin. tt. Shubh al-A'sya fi Shina'ah al-Insya', Vol. 1. Kairo: al-Mu'assasah alMishriyyah li at-Ta'lif wa at-Tarjamah.

Al-Khawarizmi. 2004. Mafatih al-'Ulum, Editor: G. Van Vloten, Pengantar: Muhammad 'Abd al-'Aziz (Serial adzDzakha'ir (118). Kairo: al-Hai'ah al-'Ammah li Qushur ats-Tsaqafah.

An-Nadim. tt. al-Fihrist, Editor: Muhammad Ahmad Ahmad. Kairo: Maktabah Tawfiqiyyah.

As-Samira'i, Zhamya' Abbas. 2010. al-Hibat al-Haniyyat fi al-Mushannfat al-Ja'bariyyah, dalam Majalah "Ma'had al-Makhthuthat al-'Arabiyyah" edisi 54, j. 2 Dzu alOa'dah 1431/November.

At-Tahanawi, Muhammad 'Ali. 1996. Kasysyaf Isthilahat al'Ulum wa al-Funun, j. 1, Tahkik: Dr. 'Ali Dahruj. Lebanon: Maktabah Lubnan Nasyirun, cet. I.

Azhari, Susiknan. 2005. Ensiklopedi Hisab Rukyat. Yogyakarta: Pustaka Pelajar.

El-Syanthy, 'Isham Mohammad. tt. Thuruq Ta'rikh an-Nusakh fi al-Makhthuthat: an-Nasy'ah wa al-Hall, Diktat Mata Kuliah 'Fahrasah al Makhthuthaat' Institut Manuskrip Arab, Kairo.

Hill, Donald R.. 2004. al-'Ulum wa al-Handasah fi alHadharah al-Islamiyyah, Terjemah: Ahmad Fu'ad Basya, Kuwait: 'Alam al-Ma'rifah.

Hitti, Philip K. 2008. History of The Arabs, Terjemah: R. Cecep Lukman Yasin \& Dedi Slamet Riyadi. Jakarta: Serambi Ilmu Semesta, cet. I.

Ibrahim al-Akfani, Muhammad bin. tt. Irsyad al-Qashid Ila Asna al-Maqashid, Tahkik: Abd al-Mun'im Mahmud Umar. Kairo: Dar al-Fikr al-Arabi.

Khalifah, Hajji. tt. Kasyf azh-Zhunun 'an Asamy al-Kutub wa al-Funun, j. 1 Beirut: Dar Ihya' at-Turats al-'Araby.

King, David A. \& Kennedy, E.S. 1886. Ibn al-Majdi's Table for Calculation Ephemerides, dalam "Islamic Mathematical Astronomy," London: Variorun Reprints.

King, David A. 1886 The Astronomy of The Mamluks, dalam "Islamic Mathematical Astronomy" London: Variorun 
Reprints.

1886. Astronomical Timekeeping

in Fourteenth - Century Syria, dalam "Islamic Math-

ematical Astronomy" London: Variorun Reprints.

1993. Mikat, dalam "The

Encyclopaedia of Islam", Volume VII (New Edition).

Leiden - New York: E.J. BRILL, 1993.

.tt. 'Ilm al-Falak wa al-Mujtama' al-

Islami, dalam "Mawsu'ah Tarikh al-'Ulum al-'Arabiyyah",

j. 1, Editor: Rusydi Rasyid. Markaz Dirasat al Wahdah al 'Arabiyyah \& Mu'assasah 'Abd al-Hamid Syuman..

Mahjub, Fatimah. tt., al Mawsu'ah az Dzahabiyyah li al'Ulum al-Islamiyyah, Vol. 19, Kairo: Dar al-Ghad alAraby.

Mu'min, Abd al-Amir. 2006. Qamus Dar al-'Ilm al-Falaky, (Beirut: Dar al-'Ilm li al-Malayin, cet. 1.

Nillino, Carlo. tt. 'Ilm al-Falak Tarikhuhu 'Inda al-'Arab fi alQurun al-Wustha (Kairo: Maktabah ats-Tsaqafah adDiniyyah.

Rajab al-Majdi, Ahmad bin. 2008. Ghunyah al-Fahin wa athThariq Ila Hall at-Taqwim, Tahkik \& Dirasah: Arwin Juli Rakhmadi. Tesis Master, 2008.

Thaz, Oashr al-Amir. 2008. Ibn Khaldun Baina al-Andalus wa Mishr. Kairo. 